\title{
Pennypack Creek Drainage Basin Erosion History: Bucks, Montgomery, and Philadelphia Counties, PA, USA
}

\author{
Eric Clausen ${ }^{1}$ \\ ${ }^{1}$ Jenkintown, PA (USA) 19046 \\ Correspondence: Eric N. Clausen, 100 West Ave D-17, Jenkintown, PA, 19046, USA. E-mail: \\ eric2clausen@gmail.com
}

Received: December 29, 2016

Accepted: February 7, 2017 Online Published: February 27, 2017

doi:10.5539/jgg.v9n1p37

URL: http://dx.doi.org/10.5539/jgg.v9n1p37

\begin{abstract}
Topographic map evidence is used to interpret Pennypack Creek drainage basin erosion history in and north of the City of Philadelphia, Pennsylvania (USA). Southwest and west-southwest oriented through valleys crossing the south oriented Pennypack Creek drainage basin, barbed Pennypack Creek tributaries, and significant valley direction changes are used to determine that the Pennypack Creek valley eroded headward across massive southwest oriented floods. Initially floodwaters flowed on a low gradient topographic surface at least as high, if not higher, than the highest Pennypack Creek drainage basin elevations today. Shallow low gradient diverging and converging flow channels were eroded into the underlying bedrock surface predominantly along fault lines and other zones of easier to erode materials. Headward erosion of the much deeper Pennypack Creek valley across this anastomosing channel complex captured southwest oriented floodwaters and flow on northeast ends of beheaded channels was reversed so as to move toward the newly eroded and deeper Pennypack Creek valley. These reversed flow channels captured southwest oriented floodwaters still moving north of the actively eroding Pennypack Creek valley head. This captured water then moved in a northeast direction and eroded deep northeast oriented valleys headward from the newly eroded Pennypack Creek valley. These valleys today account for northeast and east oriented Pennypack Creek valley segments and northeast oriented (barbed) tributaries flowing to south oriented Pennypack Creek. The floodwater source cannot be determined from Pennypack Creek drainage basin evidence, but was from the northeast. Melting of a continental ice sheet could produce floods of sufficient volume and duration to overwhelm whatever drainage system previously existed and to erode new drainage basins in a manner similar to how the Pennypack Creek drainage basin was eroded.
\end{abstract}

Keywords: barbed tributary, Delaware River, geomorphology, Neshaminy Creek, through valley, Tookany (Tacony) Creek, topographic map interpretation, Wissahickon Creek

\section{Introduction}

\subsection{Why Study Pennypack Creek Drainage Basin Erosion History}

Pennypack Creek originates in the Piedmont Lowland Section north of Philadelphia, and flows in a south direction for approximately 40 kilometers to enter and cross the Piedmont Upland Section and flow through northeast Philadelphia before joining the southwest oriented Delaware River. Immediately west of the Pennypack drainage basin is the smaller Tookany (Tacony) Creek drainage basin, which is located entirely in the Piedmont Upland Section and which also drains to the Delaware. West of the Tookany (Tacony) drainage basin and of the northern Pennypack drainage basin is the south oriented Wissahickon Creek drainage basin, which drains to the southeast oriented Schuylkill River. East of the Pennypack drainage basin is the smaller Poquessing Creek drainage basin and north and east of the Poquessing basin is the larger and south oriented Neshaminy Creek drainage basin, both of which also drain to the southwest oriented Delaware River. East of the Neshaminy drainage basin is a south and southeast oriented Delaware River segment, which near Trenton, NJ turns to become the southwest oriented Delaware River.

Several south and southeast Pennsylvania streams and rivers including the Schuylkill River, Wissahickon Creek, Pennypack Creek, and Neshaminy Creek begin on or flow across the Gettysburg-Newark Section of the Piedmont Lowland Province (as defined by Potter, 1999) before flowing in south or southeast directions into and across the Piedmont Upland Section of the Piedmont Province. Most southeast Pennsylvania geologic structures have northeast to southwest (or east-northeast to west-southwest) orientations and it is puzzling why these south 
and southeast oriented streams and rivers flow across the structures and from easily eroded bedrock regions into and then across more erosion resistant bedrock regions.

Erosional landforms by their very nature were shaped when running water removed surface material. Sometimes the removed debris was deposited nearby and those sediments now are evidence for the landscape shaping erosion events, but often water carried the removed debris great distances and landforms seen today may be the only evidence significant erosion events ever occurred. Detailed study of erosional landforms contained within and surrounding a modern day drainage basin, such as the Pennypack Creek drainage basin, can identify significant erosion events independently of sediment deposits and by doing so determine whether the described sedimentary record, if there is one, has identified all erosion events (and also determine whether the sediment record has been correctly interpreted).

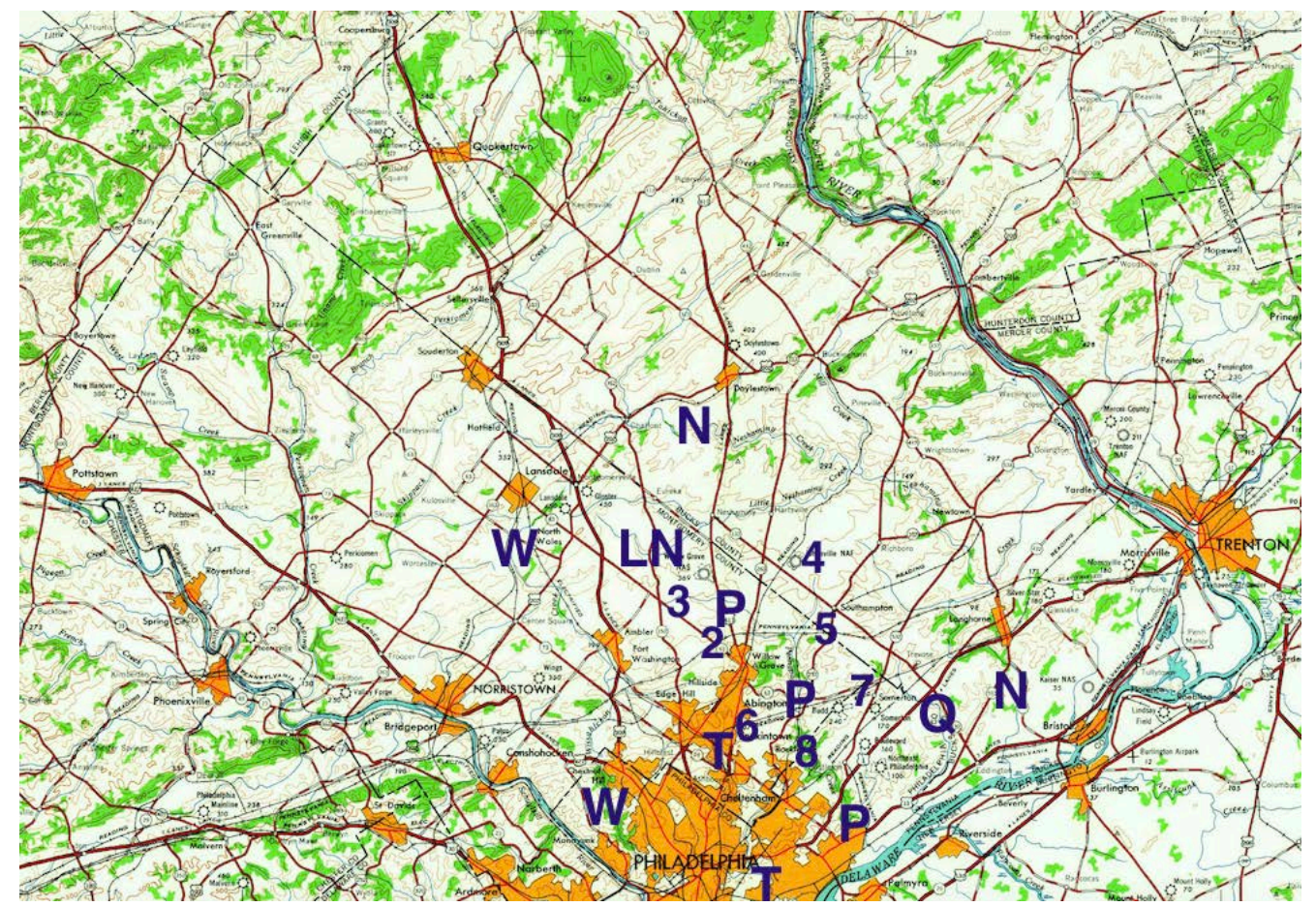

Figure 1. United States Geological Survey (USGS) map showing the Pennypack Creek location in relation to Philadelphia and adjacent drainage routes. South oriented streams are identified by letters as follows: P-

Pennypack Creek, T-Tookany (Tacony and Frankford) Creek, W-Wissahickon Creek, Q-Poquessing Creek, and N-Neshaminy Creek. LN identifies Little Neshaminym, which flows to Neshaminy Creek. Numbers correspond with Figure numbers in this paper and show approximate locations of the detailed topographic maps used in those Figures. Latitude and longitude numbers identify the Pennypack Creek headwaters and where Pennypack Creek empties into the southeast and southwest oriented Delaware River. The Schuylkill River flows in a southeast direction across the Figure 1 southwest corner and joins the Delaware River south of Figure 1.

In the Piedmont Province Upland Section the smaller south oriented Tookany (Tacony) drainage basin is directly west of the Pennypack drainage basin and was determined by Clausen (2016) to have formed when headward erosion of the south oriented Tookany Creek valley captured southwest and west oriented floods. Prior to being captured floodwaters flowed in shallow diverging and converging channels formed on a low gradient topographic surface equivalent in elevation to highest regional elevations today. Headward erosion of the deeper south oriented Pennypack Creek valley (east of the Tookany drainage basin) and of west oriented Wissahickon Creek tributary valleys (north of the Tookany drainage basin) ended all flood flow to the Tookany drainage basin. This paper uses topographic map evidence to demonstrate that Clausen's flood erosion hypothesis also explains all major Pennypack Creek drainage basin erosional landforms.

\subsection{Previous Research Related to the Pennypack Creek Drainage Basin Erosion History}

No recent publications describing or explaining specific Pennypack Creek drainage basin erosional landforms or the larger drainage basin's erosional history were found, however the Pennypack Creek drainage basin has been extensively studied for other reasons. Being located in a heavily populated region the Philadelphia Water 
Department (e.g. 2009) and others (e.g. Ham, J., Toran, L., \& Cruz, J., 2006; Sorrentino, J. A., Featherstone, J., \& Meenar, M. M. R., 2007; and Klein, T \& Toran, L., 2016) have studied specific Pennypack Creek drainage basin environmental problems. Steele (2010) has written a detailed account of how the Pennypack Ecological Trust assembled many hundreds of acres of land adjacent to Pennypack Creek. Similar land acquisition and reclamation efforts have created large watershed parks and nature preserves, including Philadelphia's Pennypack Park, adjacent to the Pennypack Creek valley. These restored natural areas attract many tens of thousands of visitors each year.

Bascom, Clark, Darton, Kummel, Salisbury, Miller, \& Knapp (1909) in a comprehensive United States Geologic Survey geologic study of the entire Philadelphia region made several comments pertinent to Pennypack Creek drainage basin erosion history. Their only specific mention of Pennypack Creek (p. 3) says it "rises on the Triassic formation and flows across the ancient crystalline rocks, and is therefore a composite stream." However in more general comments they state (p. 18) the larger regional streams maintain courses "independent of the lithologic character and structure of the underlying rock..." because this drainage was superimposed on a "cover of Cretaceous, Tertiary, or Quaternary materials which, existing at the time of the development of the drainage, masked the pre-Paleozoic and Paleozoic formations beneath it." Once formed this drainage "...became too well-established in courses consequent on the slope of the Plateau and independent of the concealed rock floor to alter these courses when subsequently the rock floor was uncovered". They also note, "The cover of Cretaceous, Tertiary, and Quaternary formations has been so far removed as to lay bare large areas of the crystalline peneplaned floor."

The lack of evidence for the hypothesized Cretaceous, Tertiary, and Quaternary materials that reportedly permitted larger Piedmont region streams, like Pennypack Creek, to be superimposed across the underlying structures led to a much larger and still unresolved $20^{\text {th }}$ century debate that not only included the origin of Piedmont drainage routes like Pennypack Creek, but that became focused on the origin of major rivers flowing across the Appalachians such as the Susquehanna and Delaware and its Schuylkill River tributary. Authors including Fenneman (1938), Thornbury (1965), and Morisawa (1989) summarize debate stages but offer little information of use in understanding Pennypack Creek erosion history. Strahler (1945) considered the problem unproductive and subsequently (1952) developed quantitative geomorphology. Determining the origins of specific drainage basins by studying valley orientations, water and wind gaps, drainage divides, through valleys crossing drainage divides, barbed tributaries, elbows of capture, and similar erosional landforms has since been considered by many researchers an exercise in frustration and such studies have almost completely disappeared from the scientific literature.

The Pennsylvania digital geologic map found at the DCNR Interactive Map Resources website shows undifferentiated Tertiary age Pensauken and Bridgeton Formations capping uplands surrounding downstream Pennypack valley segments closest to the Delaware River (no Cretaceous, Tertiary, or Quaternary sediments are mapped elsewhere in the Pennypack drainage basin). Pensauken and Bridgeton sediments are not shown in the Pennypack valley or in valleys of other south and southeast oriented Delaware tributaries suggesting valley erosion may have occurred after or during their deposition. Owens (1999) describes the Bridgeton as an immature gravelly sand of possible middle or late Miocene age with boulders being a common constituent and the Pensauken as gravelly sand with quartzite boulders up to 5 feet in diameter of upper middle to late Miocene age that was deposited on an eroded Bridgeton surface.

Stanford (2010, p. 122) suggested "the Pensauken is a preglacial fluvial deposit that aggraded during the mid-Pliocene sea-level highstand at about 3.5 million years ago.” He further said, "The Pensauken river was diverted southwestward in the New York City area during the pre-Illinoian glaciation sometime between 2.5 million and 800,000 years ago..." and that "During the early and middle Pleistocene (800,000 to 150,000 years ago), the south oriented Delaware and its tributaries eroded narrow inner valleys as much as 120 to 150 feet into the Pensauken plain.” Braun, Pazzaglia, and Potter (2003) also commented "the upper Cenozoic stratigraphy and sedimentology of the lower Delaware valley and Coastal Plain indicates that the Hudson River drained through that region and the [present day south and southeast oriented] Delaware was a very minor tributary of that [southwest oriented drainage] system until the Plio-Pleistocene.” While upper Cenozoic sediments on uplands surrounding the Pennypack valley segment closest to the southwest oriented Delaware River provide evidence for southwest oriented flows no such sediment evidence exists in the much larger upstream Pennypack Creek drainage basin.

\section{Method}

Topographic map interpretation techniques provide an extremely powerful, but often neglected research tool 
useful in determining a drainage basin's erosional history. The United States Geological Survey (USGS) published a detailed topographic map of the Pennypack Creek drainage basin in 1899 when it released the Germantown 1:62,5000 scale topographic map with a 20 foot contour interval. Maps used in this study were obtained from the USGS Historical Map Collection website and from the Pennsylvania Department of Conservation and Natural Resources (DCNR) Interactive Map Resources website, where digital versions of USGS topographic maps can be scrolled in any desired direction. Most data used in this study was obtained from the DCNR Interactive Map Resources website and was originally published as the USGS 1997 Frankford 1:24,000 map, USGS 1997 Germantown 1:24,000 map, USGS 1999 Ambler 1:24,000 map, and USGS 1999 Hatboro 1:24,000 map. The DCNR Interactive Map Resources website digital geologic map was used to identify underlying bedrock geologic units. Elevations on these maps are shown in feet and for that reason all elevations given in this paper are in feet.

This study began by determining the type of drainage system that crossed the region prior to Pennypack Creek drainage basin development. Evidence for the pre-existing drainage system was first found by looking for through valleys, wind gaps, and even minor saddles located along each of the drainage divides surrounding the modern day Pennypack drainage basin. These drainage divide crossings were identified on the most detailed topographic maps available where having a small contour interval is much more important than map scale. These divide crossings are now drained in different directions with one direction being toward Pennypack Creek and the other direction being toward an adjacent drainage route. These divide crossings are evidence that water once flowed in one direction or the other in a channel that crossed the modern day drainage divide. Dismemberment of that earlier channel was an important step in creating the drainage divide and also in the formation of the separate drainage basins seen today.

Once identified the questions asked at each drainage divide crossing were, "in what direction did that original drainage channel flow and what caused the channel to be dismembered?” When answering the questions stream capture was considered to be the most likely dismemberment cause, which meant the present day drainage divide was created when headward erosion of a deeper channel beheaded flow in the original channel so as to create the drainage divide and also to reverse the direction of flow on the downstream end of the beheaded channel. Barbed tributaries were considered probable evidence that headward erosion of a deep valley had beheaded and reversed flow in shallower and low gradient channels. While differential weathering and erosion probably played a role it usually could not explain the presence of both the barbed tributary and the larger stream into which the tributary flowed. All abrupt valley direction changes, including probable elbows of capture, were also checked to determine if there was evidence that one or more of the valley segments had reversed its original flow direction.

The large number of divide crossings found along drainage divides surrounding the Pennypack Creek drainage basin and of barbed and normal Pennypack Creek tributaries identified to be relics of an earlier drainage network along with the need for a water source capable of eroding all valleys now located in the Pennypack Creek drainage basin suggested that prior to Pennypack Creek drainage basin erosion the entire region had been crossed by an anastomosing complex of diverging and converging channels moving vast quantities of water in a west or southwest direction on a low gradient topographic surface (equivalent in elevation or higher than the highest regional elevations today). Headward erosion of a deep south oriented Pennypack Creek valley from the southwest oriented Delaware River valley across this large anastomosing channel complex was considered to be the most likely reason for Pennypack Creek drainage basin erosion and the large volumes of water moving in the anastomosing channel complex were considered the most likely erosion agent. Determining if this flood erosion interpretation could explain each major drainage divide crossing, barbed tributary, and unusual valley direction change identifiable on the detailed topographic maps was the hypothesis test. The test was considered successful only after it produced a logical and consistent sequence of Pennypack Creek drainage basin erosion events, just as pieces of a picture puzzle when properly put together produce a coherent and recognizable picture.

\section{Results}

\subsection{Through Valleys Across the Pennypack-Wissahickon Creek Drainage Divide}

\subsubsection{Dreshler through valley}

Several through valleys cross the Pennypack-Wissahickon Creek drainage divide with the Dreshler through valley being the deepest and most obvious. The Dreshler through valley links a northeast and east oriented Pennypack Creek tributary with a southwest oriented Wissahickon Creek tributary. In Figure 2 the Dreshler through valley can be identified by the Pennsylvania Turnpike and adjacent rail line extending from the Wissahickon Creek valley (west) to the Pennypack Creek valley (east). The Pennsylvania DCNR Interactive Map Resources website digital geologic map shows the Dreshler through valley to be located along the boundary 
between Triassic Stockton Formation (arkosic sandstone) to the north and on the south Precambrian age felsic gneiss east of Dreshler and Cambrian age Chickies Formation (quartzite) west of Dreshler. The drainage divide elevation on the through valley floor is between 280 and 290 feet while highest drainage divide elevations to the south exceed 400 feet and to the north the highest drainage divide elevations seen in Figure 2 exceed 370 feet suggesting the through valley is at least 80 feet deep.

The Dreshler through valley northeast to southwest orientation provides a valuable clue as to which direction water once flowed. The Dreshler through valley is a western segment of a much longer through valley with other segments being the Mill-Southampton Creek through valley discussed in sections 3.2.2 of this paper and an east oriented Pennypack Creek segment in the intervening Pennypack Creek valley discussed in section 3.4.2. Since all drainage routes crossed by this east-northeast to west-southwest oriented through valley are today south oriented drainage systems the Dreshler through valley original flow direction before dismemberment is considered to have been from the northeast to the southwest. Had flow in the Dreshler through valley been the other way the flow would have joined several south oriented creeks, including Pennypack Creek as barbed tributaries and north oriented flow in the Wissahickon Creek valley would be required. Other clues possibly supporting the southwest direction of original flow are much more of the Dreshler through valley floor drains today in a southwest direction to Wissahickon Creek than drains in a northeast and east direction to Pennypack Creek and an original west-southwest flow direction is consistent with flow directions determined from other erosional landforms.

Southwest oriented water eroded the Dreshler through valley as it flowed to the south oriented Wissahickon valley. Before reaching the Dreshler through valley the water flowed across what is now the Mill Creek-Southampton Creek drainage divide (see section 3.2.2) and across what is now an east oriented Pennypack Creek valley segment discussed in section 3.4.2. This southwest oriented water eroded a southwest oriented valley headward from the Wissahickon valley along the through valley floor to the location of the present day Wissahickon-Pennypack Creek drainage divide, while northeast and east of that divide location the through valley floor was as high or higher than the present day drainage divide elevation (between 280-290 feet). Dismemberment of the southwest oriented channel that eroded the Dreshler through valley occurred when the much deeper south oriented Pennypack Creek valley (now with an elevation of about 170 feet where it crosses the Dreshler through valley) eroded headward across the west oriented channel and beheaded and reversed flow on the flow channel's east end. Once the Wissahickon-Pennypack Creek drainage divide had been created water ceased to flow across it and it is unlikely there was enough water left in the beheaded and reversed channel east end to erode the northeast and east oriented Pennypack Creek tributary valley seen today, meaning an explanation for that tributary valley is still needed.

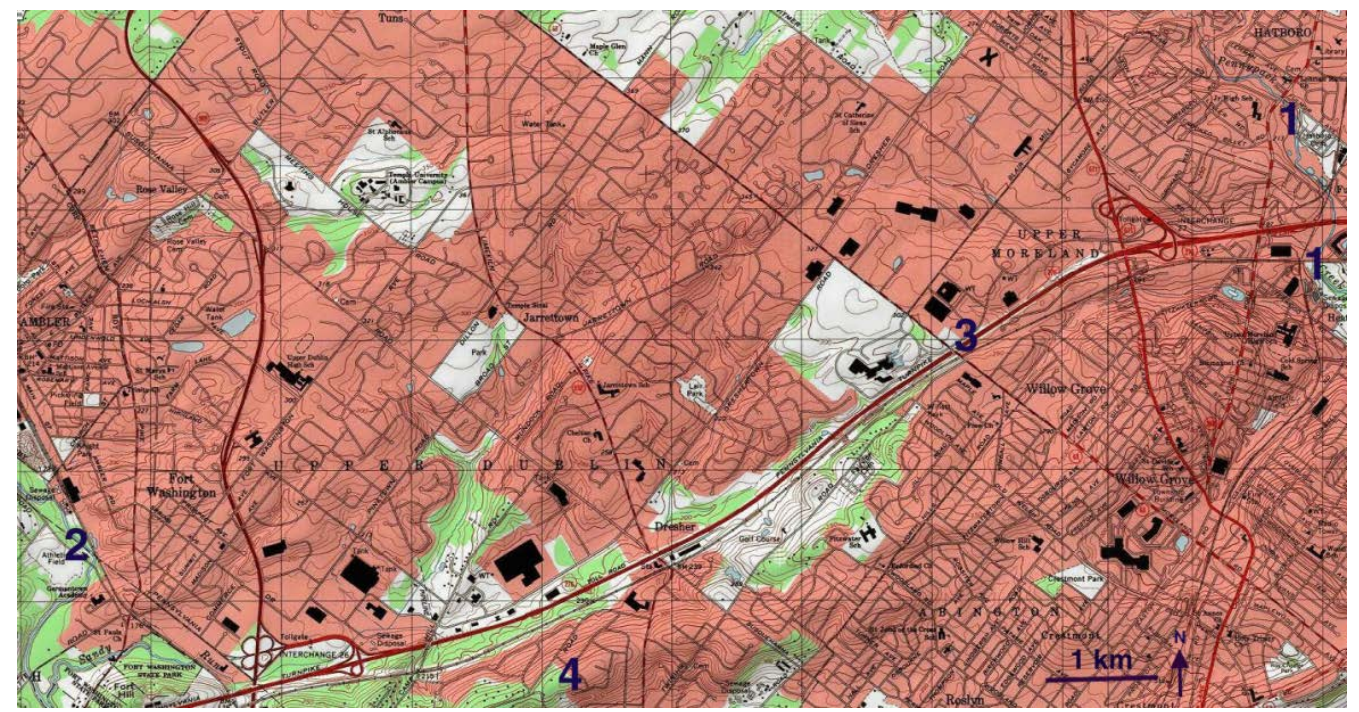

Figure 2. USGS 1:24,000 scale topographic map (10-foot contour interval) taken from Pennsylvania DCNR Interactive Map Resources website showing the Dreshler through valley between Pennypack Creek (1) and Wissahickon Creek (2). The number 3 is located at the drainage divide between the two opposing creeks

Headward erosion of the Pennypack valley across this west and southwest oriented flow channel occurred because vast quantities of water flowed across the entire northern Pennypack drainage basin on its way to the 
Wissahickon valley. This water enabled the deep Pennypack Creek valley to erode headward across the gneiss located south of the Dreshler through valley and into the Stockton Formation sandstone to the north. Before Pennypack Creek valley headward erosion into the area the immense volumes of water flowed on a topographic surface at least as high as the highest points along drainage divides surrounding the northern Pennypack drainage basin today. Water moved in shallow diverging and converging channels that had been scoured along zones of geologic weakness (e.g. fault lines and easily eroded bedrock). Pennypack valley headward erosion across this anastomosing channel complex beheaded and reversed the diverging and converging southwest oriented channels in sequence from south to north. Southwest oriented flow moving north of the actively eroding Pennypack valley head, when moving at a high enough elevation, spilled into newly beheaded and reversed flow channels with the water making a U-turns so as to flow into the newly reversed channels and move to the newly eroded and much deeper Pennypack valley. This process explains how the valley now draining the Dreshler through valley northeast and east end was eroded. Evidence of such flow in Figure 2 is seen north of the Pennsylvania Turnpike interchange with route 611 (north of Willow Grove) where a shallow through valley links the southeast oriented Pennypack valley with the tributary draining the Dreshler through valley northeast and east end.

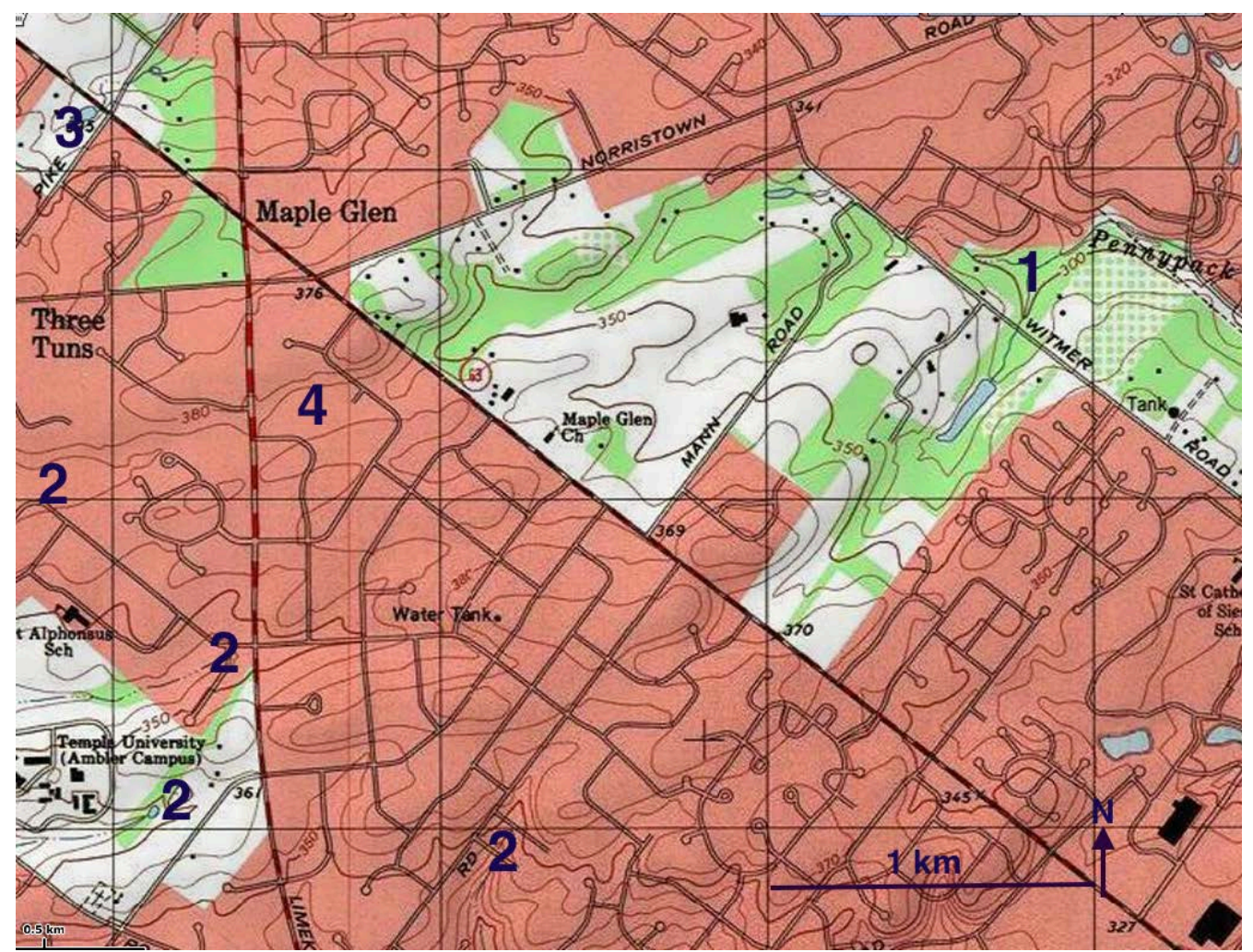

Figure 3. USGS 1:24,000 scale topographic map (10-foot contour interval) taken from the Pennsylvania DCNR Interactive Map Resources website showing Pennypack Creek headwaters (1), headwaters of several southwest oriented Wissahickon Creek tributaries are shown by the number 2, headwaters of a northeast oriented Little Neshaminy Creek tributary (3), and a shallow through valley (4) linking the Pennypack Creek headwaters with a Wissahickon Creek tributary

\subsubsection{Pennypack Creek Headwaters and Wissahickon Creek Drainage Divide Area}

North of the Dreshler through valley several shallow through valleys link northeast and east oriented Pennypack Creek headwaters with southwest oriented Wissahickon Creek tributary valleys. Perhaps the most interesting is seen in Figure 3 and links the Pennypack Creek headwaters valley with a southwest oriented Wissahickon tributary valley and has a floor elevation of between 360 and 370 feet at its drainage divide. While considerably higher than the Dreshler through valley to the south (and an unseen Little Neshaminy Creek-Wissahickon tributary through valley found further north) that through valley linking the Pennypack headwaters with a southwest oriented Wissahickon tributary valley is evidence Pennypack valley headward erosion beheaded and reversed a southwest oriented flow channel with a floor elevation of at least 360 feet after it had beheaded and 
reversed southwest oriented flow in the much deeper Dreshler through valley. This evidence, plus the fact that more and deeper northeast to southwest oriented through valleys cross the Little Neshaminy-Wissahickon divide to the north of Figure 3 is evidence that as the south oriented Pennypack valley and subsequently the east oriented Little Neshaminy valley eroded headward across the region they captured in sequence multiple southwest oriented flow channels that crossed what are now the Pennypack-Wissahickon divide and the Little Neshaminy-Wissahickon divide.

Shallow through valleys north of the Dreshler through valley are locally defined by one or more (10-foot) contour lines, but appear to be indentations on the floor of a much broader northeast to southwest oriented through valley of which the Dreshler through valley and the previously mentioned unseen through valley between a northeast oriented Little Neshaminy tributary valley and a southwest oriented Wissahickon Creek tributary are the deepest. The broader northeast to southwest oriented through valley floor includes the entire Pennypack-Wissahickon Creek drainage divide area seen in Figures 2 and 3 and much of the unseen Little Neshaminy-Wissahickon drainage divide area further to the north. South of the Dreshler through valley elevations on the Pennypack-Wissahickon Creek drainage divide rise at one point to more than 430 feet while north of Little Neshaminy-Wissahickon Creek drainage divide (near the opposing Wissahickon Creek and Little Neshaminy Creek headwaters) elevations exceed 500 feet. Between those high points all elevations along the drainage divide are lower with multiple deeper indentations such as the Dreshler through valley crossing the drainage divides. This broader through valley is evidence that immense volumes of southwest oriented flood flow significantly lowered the regional landscape. Present day high points within and near the Pennypack Creek drainage basin suggest the regional surface was probably lowered by more than one hundred feet with greatest lowering near the Delaware River valley.

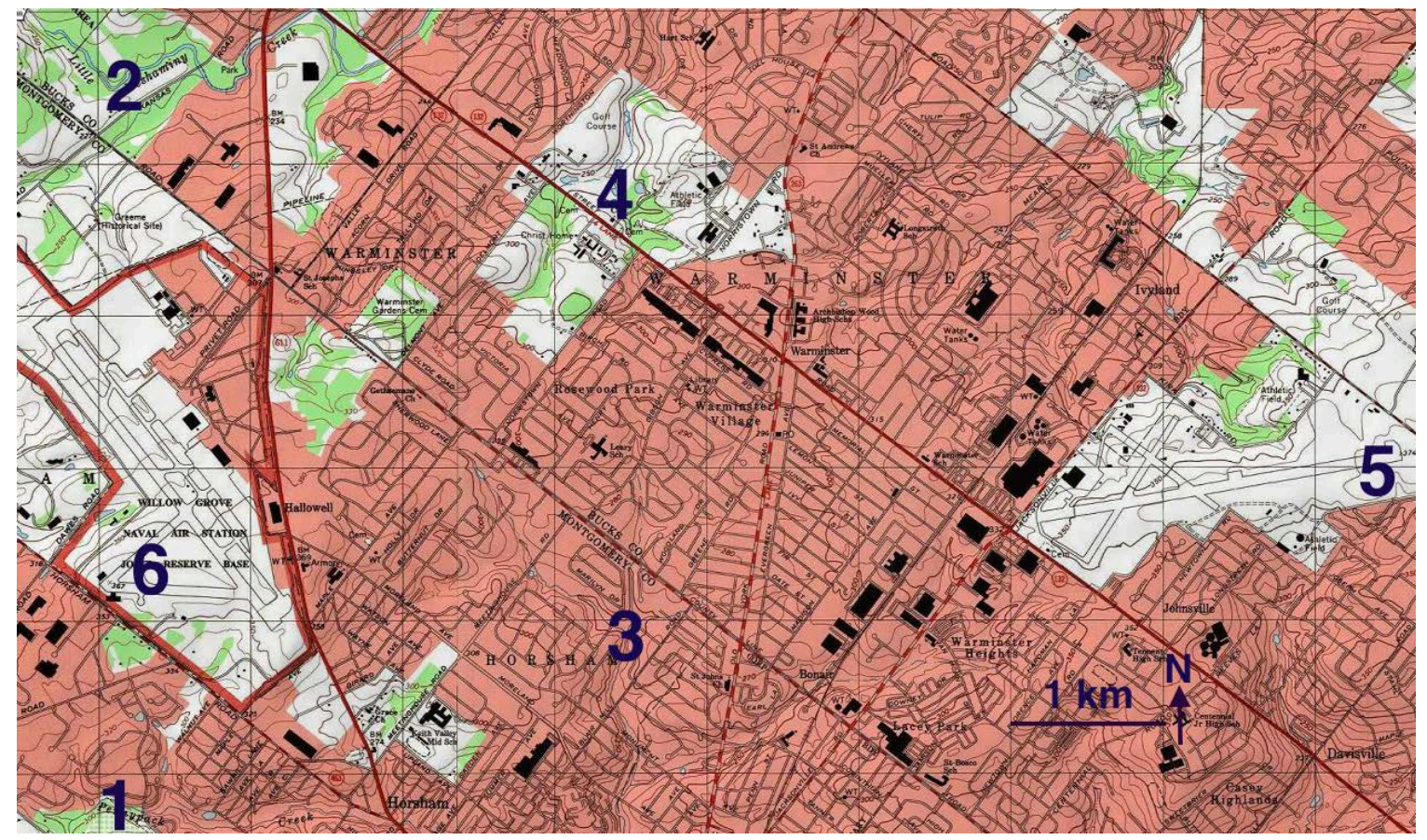

Figure 4. USGS 1:24,000 scale topographic map (10-foot contour interval) taken from Pennsylvania DCNR Interactive Map Resources website showing Pennypack Creek (1), Little Neshaminy Creek (2), a south oriented Pennypack Creek tributary (3), and a north oriented Little Neshaminy Creek tributary (4). The north to south oriented Rosewood Park through valley is between numbers 4 and 3 and has a floor elevation of between 300 and 310 feet. Spot elevations near the numbers 5 and 6 are 374 and 367 feet respectively.

\subsection{Through Valleys Across the Neshaminy-Pennypack Creek Drainage Divide}

\subsubsection{Little Neshaminy-Pennypack Creek Drainage Divide the Rosewood Park through Valley}

The Rosewood Park through valley seen in Figure 4 links a north oriented Little Neshaminy Creek tributary with a south oriented Pennypack Creek tributary and at its drainage divide has a floor elevation of between 300 and 310 feet. Elevations to the east rise to 374 feet and to the west to 367 feet and define a north to south oriented 
through valley at least 57 feet deep and depending on how it is measured up to 8 kilometers wide. The Rosewood Park through valley is cut into the Triassic age Stockton Formation (sandstone, shale, siltstone, and mudstone) and provides evidence that significant volumes of water once flowed across the Little Neshaminy-Pennypack drainage divide. Largely unseen (in Figure 4) Little Neshaminy Creek today flows in an east direction north of Figure 4 to join southeast and south oriented Neshaminy Creek, with the unseen Neshaminy Creek valley being located north and east of Figure 4. Since both the Neshaminy and Pennypack drainage basins are south oriented drainage basins the direction of flow in the Rosewood through valley was almost certainly to the south with dismemberment of that south oriented flow caused by headward erosion of the deeper east-oriented Little Neshaminy valley (from the south oriented Neshaminy Creek valley). Flow at the Rosewood Park through valley north end was reversed when Little Neshaminy valley headward erosion beheaded it to create the north oriented Little Neshaminy tributary seen today. Water to erode the north oriented Little Neshaminy tributary valley probably was derived from southwest oriented flood flow west of the actively eroding Little Neshaminy Creek valley head.

\subsubsection{Mill Creek (Neshaminy)-Southampton Creek (Pennypack) Divide}

Southampton Creek is a south and south-southwest oriented Pennypack Creek tributary and Mill Creek is a southeast and east-northeast oriented tributary to south oriented Neshaminy Creek (only the southeast oriented Mill Creek segment is seen in Figure 5).

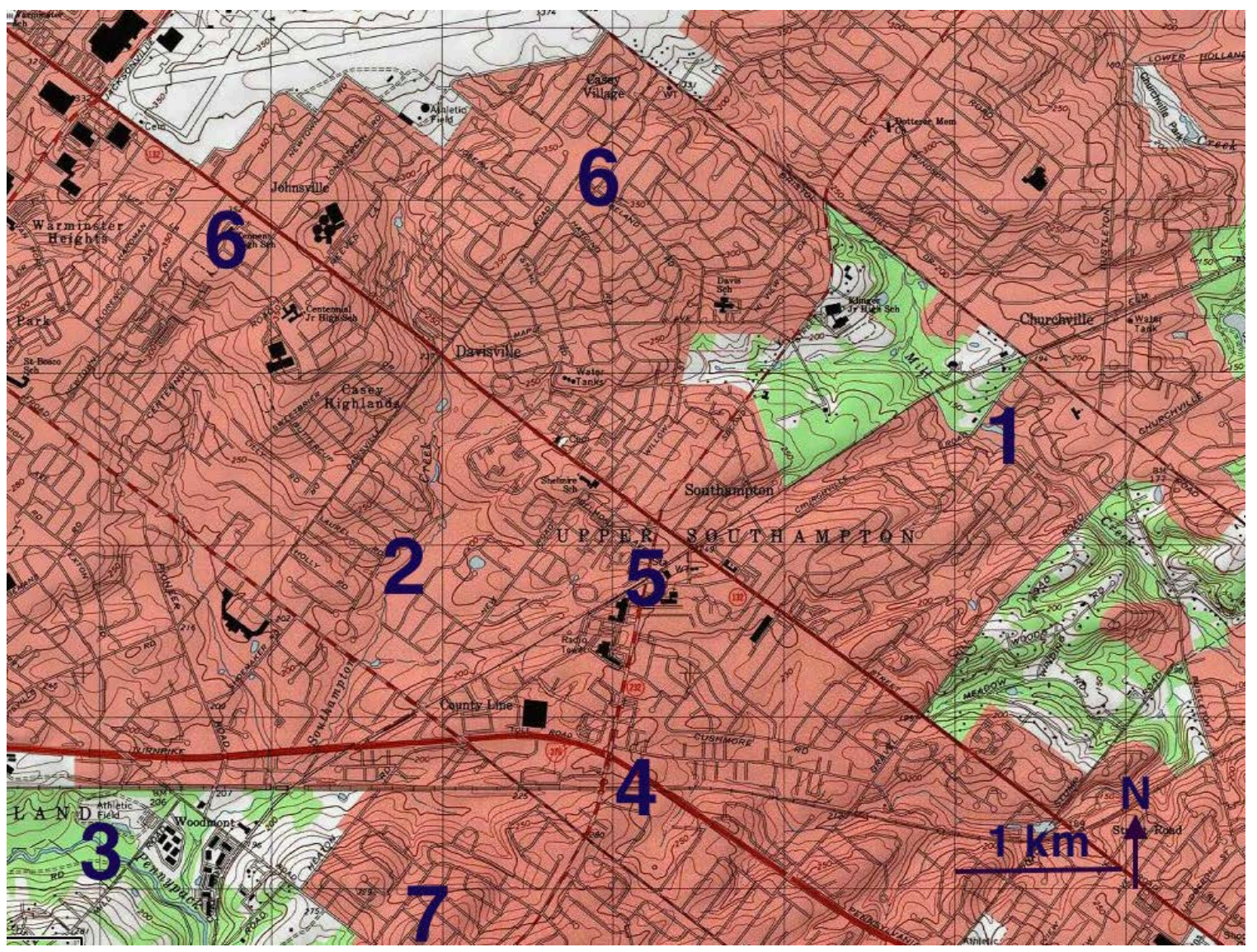

Figure 5. USGS 1:24,000 scale topographic map (10-foot contour interval) taken from Pennsylvania DCNR Interactive Map Resources website showing through valleys crossing the drainage divide between south oriented Southampton Creek (2) and the southeast oriented Mill Creek headwaters (1). Southampton Creek flows to east and south oriented Pennypack Creek (3) and Mill Creek turns in an east-northeast direction to join south oriented Neshaminy Creek. A rail line (4) crosses the drainage divide at an elevation of between 240 and 250 feet and a now abandoned rail line (5) crosses the drainage divide at an elevation of between 250 and 260 feet. Elevations at the numbers 6 exceed 360 feet and at number 7 exceed 340 feet

Through valleys on the floor of a broad through valley cross the Mill-Southampton Creek divide and are evidence that headward erosion of the southeast oriented Mill Creek valley captured west and southwest oriented 
flow moving to the Southampton Creek valley. Much of the Southampton-Mill Creek drainage divide area is lower in elevation than elevations to the north and to the south. The rail line marked by the number 4 in Figure 5 is in the deepest through valley channel and is located roughly along the boundary between the Triassic Stockton Formation (conglomerate, sandstone, shale, siltstone, and mudstone) to the north and Precambrian gneisses to the south. To the west that rail line is located in the Dreshler through valley where it crosses the Pennypack-Wissahickon Creek divide at an elevation of between 280 and 290 feet. Between Southampton and Mill Creeks the rail line crosses the drainage divide at an elevation of between 240 and 250 feet. The (now abandoned) rail line marked by the number 5 crosses the drainage divide at an elevation of between 250 and 260 feet. The two numbers 6 in Figure 5 identify locations where the elevation exceeds 360 feet and the number 7 identifies a drainage divide point where the elevation exceeds 340 feet. The through valley between the Mill and Southampton Creek valleys is more than 2 kilometers across (north to south) and at its deepest points is approximately 100 feet deep and provides evidence large volumes of west and southwest oriented water flowed from the present day Neshaminy drainage basin area across the Pennypack drainage basin to the Wissahickon valley before being captured by headward erosion of the Pennypack-Southampton Creek valley. Headward erosion of the southeast oriented Mill Creek valley then captured the west oriented flow and diverted the water to the south oriented Neshaminy Creek valley located east of Figure 5. Subsequently headward erosion of the southeast oriented Delaware River valley segment (upstream from its southwest oriented valley segment) beheaded all southwest oriented flow to the Neshaminy Creek drainage basin.

\subsection{Huntingdon Valley-A Major West-Southwest Oriented through Valley}

\subsubsection{Jenkintown-Bethayres through valley}

The Jenkintown-Bethayres segment of the Huntingdon Valley is shown in Figure 6 and is just one segment of a much longer west-southwest oriented through valley that extends from the Delaware River valley east of south oriented Neshaminy Creek across the south oriented Poquessing, Pennypack, and Tookany Creek valleys to the Chester Valley, which then extends in a west-southwest direction across the Wissahickon Creek, Schuylkill River, and Brandywine Creek valleys into the Susquehanna River drainage area. Today the Jenkintown-Bethayres segment of this extensive through valley is drained in an east-northeast direction by Meadow Brook to south oriented Pennypack Creek and in a west-southwest direction by Braederwood Creek to south oriented Tookany (Tacony) Creek. Like the Dreshler through valley the Jenkintown-Bethayres through valley segment orientation suggests original flood flow moved in a west-southwest direction. Prior to being captured by headward erosion of the deep south-oriented Tookany Creek valley Clausen (2016) suggests flow continued in a west direction along the east oriented Tookany Creek headwaters valley and then through a wind gap to a west oriented Wissahickon Creek tributary valley. The wind gap floor elevation between the west oriented Wissahickon tributary valley and the east oriented Tookany Creek headwaters valley is slightly greater than 350 feet indicating the original west-southwest oriented flow channel elevation to the east of that wind gap was at least 350 feet high if not higher.

The Jenkintown-Bethayres through valley floor drainage divide today has an elevation slightly greater than 230 feet and is located east of where Baederwood Creek enters the through valley. West-southwest oriented flow moving to the newly eroded and deep south oriented Tookany Creek valley lowered the Jenkintown-Bethayres through valley floor elevation by more than 120 feet to approximately the level of its modern day drainage divide (230 feet) with all valley floor elevations to the east at that time still being higher than 230 feet. Upstream from the Jenkintown-Bethayres through valley Baederwood Creek flows in a south direction and is linked by a shallow northern through valley with a northeast and southeast oriented Pennypack Creek tributary. The northern through valley floor elevation at its drainage divide is between 300 and 320 feet. Today Baederwood Creek joins Tookany Creek at an elevation of between 210 and 220 feet. These elevations suggest west-southwest oriented water at one time flowed at a much higher elevation in the northern through valley and was captured by headward erosion of the south oriented Baederwood Creek valley from the deeper Jenkintown-Bethayres through valley.

Headward erosion of the deep south oriented Pennypack Creek valley captured the west-southwest oriented flow moving to the south oriented Tookany Creek valley and caused a reversal of flow in the beheaded Jenkintown-Bethayres through valley flow channel. Today Pennypack Creek crosses the Huntingdon Valley through valley at an elevation of between 130 and 140 feet and a significant section of the Jenkintown-Bethayres through valley is now drained by east-northeast Meadow Brook to Pennypack Creek. Near the Pennypack Creek valley the reversed flow lowered the Meadow Brook valley by almost 100 feet with decreasing amounts of erosion in a west direction toward the modern day through valley floor drainage divide. Erosion of the Meadow Brook valley required considerable volumes of water and water that eroded the east-northeast oriented Meadow 
Brook valley came from what at that time was the previously mentioned and yet to be beheaded (by Pennypack Creek valley headward erosion) northern (southwest oriented) flow channel draining to the south oriented Baederwood Creek headwaters valley (and possibly from other channels further to the north). That northern flood flow channel was located between the Highland School and the Abington Memorial Hospital with water flowing north of Abington High School and then turning in a south direction to flow through Baederwood Park along the present day south oriented Baederwood Creek route, which today enters the west-southwest oriented Jenkintown-Bethayres through valley near the Tookany-Pennypack divide. West oriented water from this route in addition to flowing to the south oriented Baederwood Creek valley probably spilled south at other locations into the beheaded and reversed Jenkintown-Bethayres through valley until headward erosion of the southeast oriented Pennypack tributary valley beheaded and reversed the northern flow route to create the northern Baederwood Creek-Pennypack Creek tributary drainage divide.

\subsubsection{Bethayres-Somerville through Valley}

East of Pennypack Creek the Huntingdon Valley provides a link to the south oriented Poquessing Creek valley and is here referred to as the Bethayres-Somerville through valley as seen in Figure 7. The west-southwest end of this through valley segment is drained by southwest oriented Huntingdon Valley Creek, which once in the through valley flows in a west-southwest direction to join south oriented Pennypack Creek. The through valley segment's east-northeast end is drained by a south oriented stream flowing through Forest Hill Cemetery that enters the through valley near the Pennypack-Poquessing Creek divide and then turns to flow in an east-northeast direction before joining south oriented Poquessing Creek. As seen in Figure 7 the Pennypack-Poquessing Creek divide on the through valley floor is roughly midway between the two south oriented creeks and has an elevation of between 190 and 200 feet.

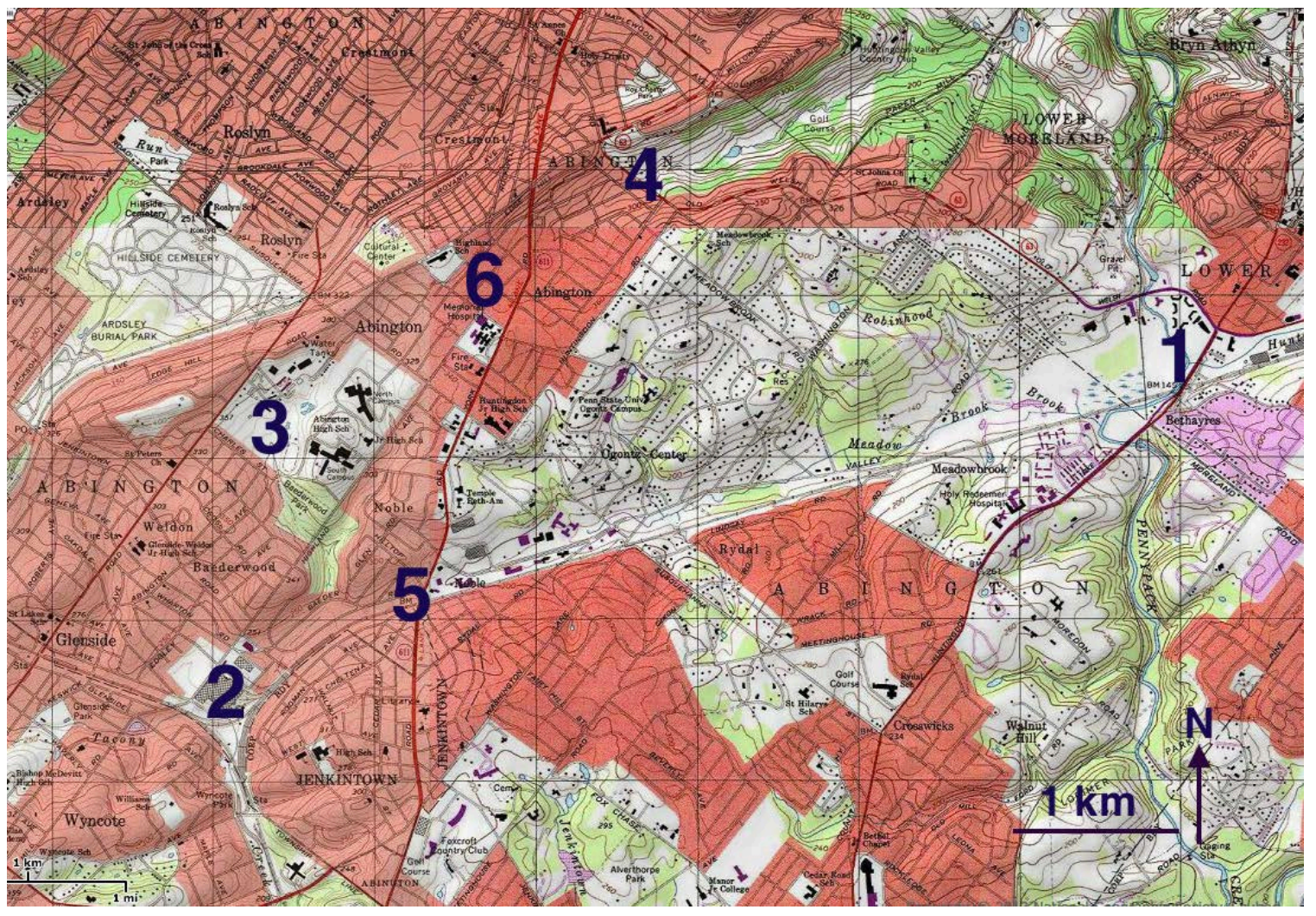

Figure 6. USGS 1:24,000 scale topographic map taken from Pennsylvania DCNR Interactive Map Resources website showing the Jenkintown-Bethayres through valley segment of the Huntingdon Valley (20-foot contour interval south and east of the number 6 and 10-foot contour interval elsewhere). The number 1 identifies where

Pennypack Creek crosses the Huntingdon Valley, 2 the elbow of capture where Tookany Creek turns from an east

direction to a south direction, 3 headwaters of south and west-southwest oriented Baederwood Creek, 4 headwaters of a northeast and southeast oriented Pennypack Creek tributary, 5 location of the

Pennypack-Tookany Creek divide on the Huntingdon Valley floor, and 6 location of the Baederwood Creek-Pennypack tributary divide on the northern through valley floor 
The Pennsylvania DCNR Interactive Map Resources website digital geologic map shows the Bethayres-Somerville through valley is located along the boundary between Precambrian felsic gneiss (north) and Wissahickon Schist of probable early Paleozoic age (south) with a narrow slice of Cambrian Ledger Formation dolomite found between the two. Based on these geologic relationships and rare earthquake epicenter locations the through valley is sometimes associated with the Huntingdon Valley Fault zone (Bischke, 1980). Prior to regional erosion massive southwest oriented floods moving across a high level and now removed topographic surface scoured a shallow low gradient west-southwest oriented channel along the fault line and narrow slice of Ledger Formation dolomite. West-southwest oriented flood flow in this channel to the Pennypack valley was beheaded by headward erosion of the south oriented Poquessing Creek valley with flow on the east-northeast end of the beheaded channel being reversed to create the (south and then) east-northeast oriented Poquessing Creek tributary that drains the through valley floor east end today. Headward erosion of the unseen and deep south oriented Neshaminy Creek valley (east of Figure 7) next captured the west-southwest oriented flood flow.

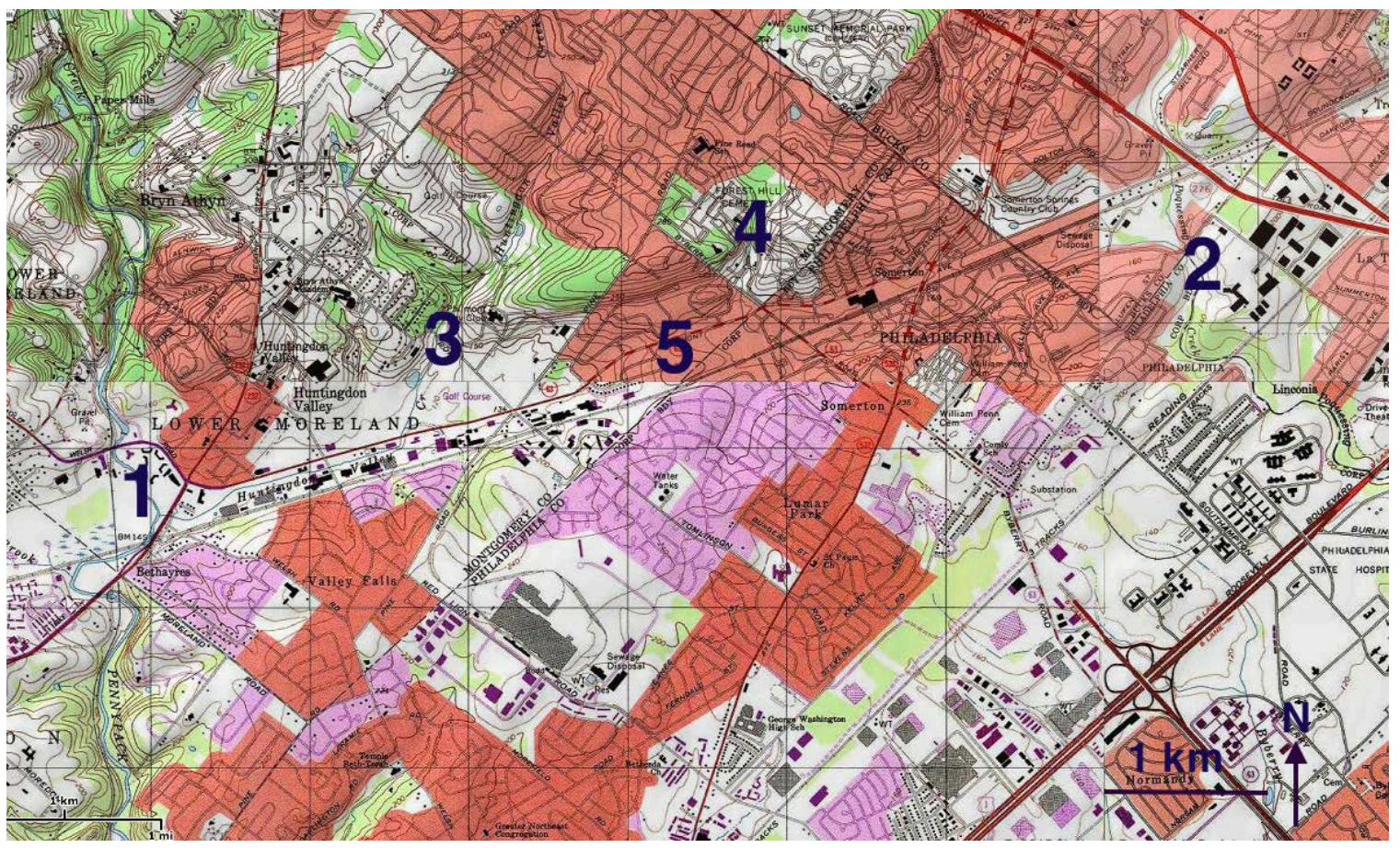

Figure 7. USGS 1:24,000 scale topographic map (20-foot contour interval in south half and along west edge, 10-foot contour interval elsewhere) taken from Pennsylvania DCNR Interactive Map Resources website showing the Huntingdon (through) Valley between Pennypack Creek (1) and Poquessing Creek (2). Huntingdon Valley Creek (3) flows in a southwest and west-southwest direction to Pennypack Creek and the creek at the number 4 flows in a south and then east-northeast direction to Poquessing Creek. The through valley floor drainage divide is at the number 5

\subsection{Pennypack Creek Barbed Tributaries and an Unusual Direction Changes}

\subsubsection{Barbed tributaries and Direction Changes}

Several barbed tributaries and unusual direction changes provide further evidence the south oriented Pennypack Creek valley eroded headward across southwest or west-southwest oriented anastomosing flow channels. The Dreshler through valley eastern end seen in Figure 2 is drained by a northeast, east, and southeast oriented Pennypack Creek tributary. Figure 3 shows northeast oriented drainage routes turning in a southeast direction in the Pennypack Creek headwaters area. East-northeast oriented Meadow Brook seen in Figure 6 joins south oriented Pennypack Creek as a barbed tributary. Also in Figure 6 a northeast and southeast oriented Pennypack Creek tributary is located north of the Huntingdon Valley while south of the Huntingdon Valley several barbed tributaries flow in northeast directions to join south oriented Pennypack Creek. Figure 8 better illustrates Pennypack Creek northeast oriented barbed tributaries from the west and southwest oriented tributaries from the east in the region immediately south of the Huntingdon Valley and also shows an intriguing direction change 
where south oriented Pennypack Creek first turns in a southwest direction to join a northeast oriented (barbed) tributary and then abruptly turns in an east-northeast direction before finally turning in a south direction again. Each of the Pennypack Creek barbed tributaries, the northeast to southeast oriented tributary direction changes, and the Pennypack Creek abrupt southwest to east-northeast direction change are unusual features that need to be explained.

The northeast oriented barbed tributaries, like in the case of the Dreshler through valley, are best explained by Pennypack valley headward erosion across shallow and low gradient diverging and converging southwest oriented flood flow channels with floodwaters spilling freely across divides between the anastomosing flow channels. Headward erosion of the much deeper south oriented Pennypack valley not only captured the southwest oriented flow, but also reversed flow on the beheaded low gradient channels so as to move water in a northeast direction towards the much deeper Pennypack valley. Because the channels diverged and converged and also because water spilled across divides between the shallow channels the reversed flow channels captured significant flow that was still moving in a southwest direction north of the actively eroding Pennypack valley head. This capture of floodwaters from north of the actively eroding Pennypack valley head supplied sufficient volumes of water to the reversed flow channels so as to erode deep northeast oriented tributary valleys before continued headward erosion of the Pennypack valley beheaded the northern southwest oriented flow channels. The same concept also explains why some Pennypack Creek tributaries flow in a northeast and then southeast directions. Headward erosion of the southeast oriented valley beheaded and reversed southwest oriented flow channels.

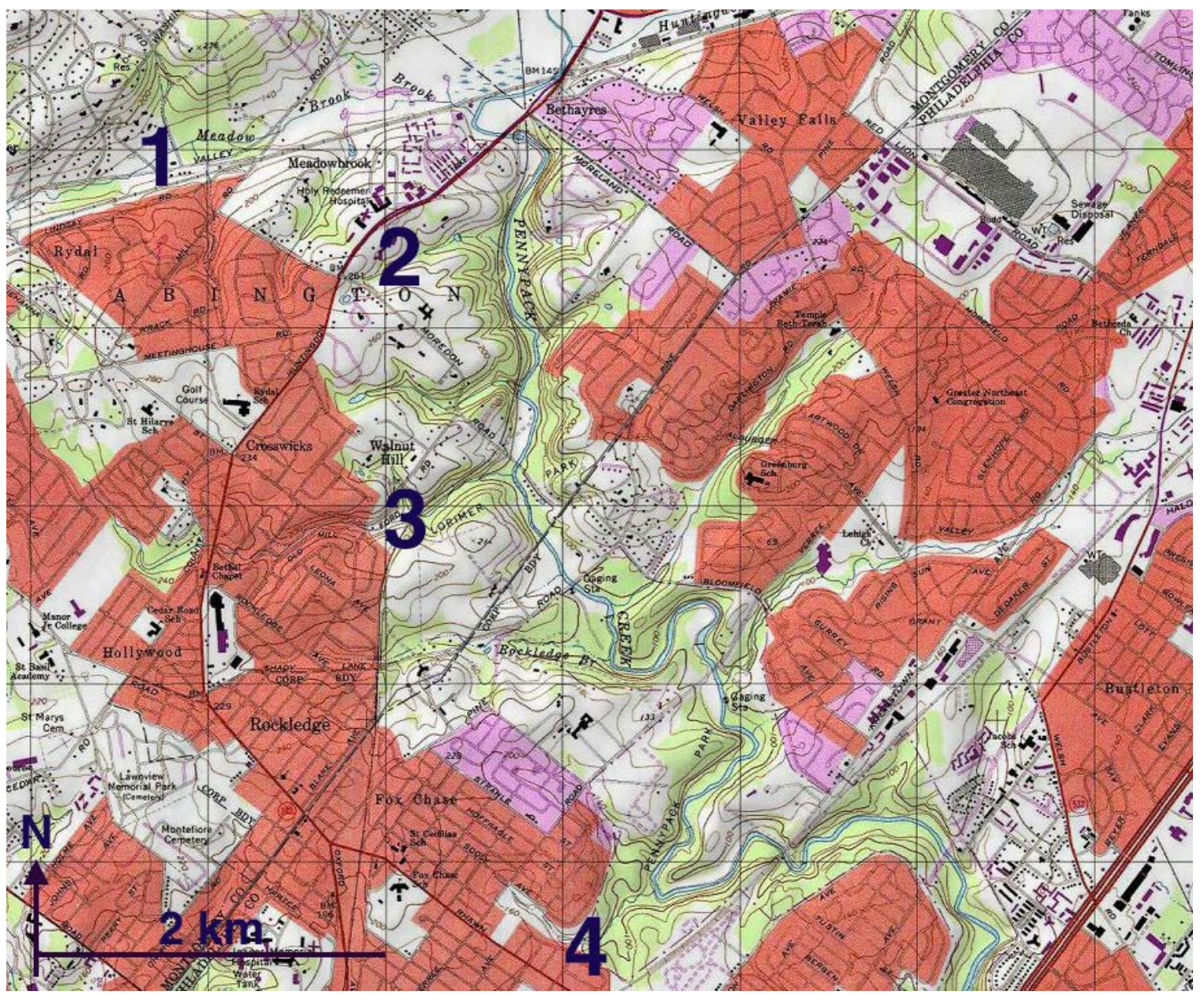

Figure 8. USGS 1:24,000-scale topographic map (20-foot contour interval) taken from the Pennsylvania DCNR

Interactive Map Resources website showing Pennypack Creek barbed tributaries and direction changes downstream from the Huntingdon Valley. Number 1 identifies Meadow Brook in the Huntingdon Valley and the numbers 2, 3, and 4 identify barbed tributaries flowing in northeast directions to south oriented Pennypack Creek. Pennypack Creek makes an abrupt southwest to east-northeast direction at the point where the northeast oriented tributary at number 4 joins it 
An example of evidence showing how reversed flow channels captured water can be seen in Figure 8 where south oriented Pennypack Creek turns in a southwest direction to meet a northeast oriented (barbed) tributary and then turns abruptly in an east-northeast direction before resuming its southward flow. Prior to headward erosion of the deep Pennypack Creek valley a shallow west-southwest oriented flow channel converged with a shallow southwest oriented channel (from the north) to form a southwest oriented flow channel along what is now the northeast oriented (barbed) tributary alignment. This southwest oriented flow channel continued across the Pennypack-Tookany Creek drainage divide in what Clausen (2016) referred to as the Cheltenham through valley and then in a southwest direction along what is now a southwest oriented Tookany (Tacony) Creek valley segment. Headward erosion of the deep south-oriented Pennypack valley beheaded and reversed flow on the shallow west-southwest oriented flow channel east end to create the east-northeast oriented Pennypack Creek valley segment. The newly reversed channel then captured flow from the southwest oriented flow channel (from the north) to create what is today the Pennypack Creek abrupt southwest to east-northeast direction change. The capture of the northern southwest oriented flow channel also reversed flow on the northeast end of the beheaded southwest flow channel that had been moving water to the southwest oriented Tookany (Tacony) Creek valley segment and this created the northeast oriented tributary that now joins Pennypack Creek at its abrupt direction change.

\subsubsection{Pennypack Creek between the Dreshler and Mill-Southampton Creek through valleys}

The Dreshler though valley crosses the Pennypack-Wissahickon drainage divide and is a western extension of the Mill-Southampton Creek through valley, which crosses the Neshaminy-Pennypack drainage divide to the east. An intriguing east oriented Pennypack Creek valley segment links these two west oriented through valleys and provides further evidence the deep south oriented Pennypack valley captured flow in a west-southwest oriented channel that once extended at least from east of the present day Neshaminy Creek valley to the modern day Wissahickon Creek valley. The east oriented Pennypack Creek valley segment is illustrated in Figure 9. The rail line adjacent to the Pennsylvania Turnpike follows the extended through valley from the Wissahickon Creek valley to the Neshaminy Creek valley and is seen crossing the Southampton-Mill Creek drainage divide at number 4 in Figure 5. Pennypack Creek crosses the 170-foot contour line in this east oriented segment while as previously discussed the Dreshler through valley divide elevation is between 280 and 290 feet and the Mill-Southampton Creek through valley divide elevation is between 240 and 250 feet. These elevations suggest the Mill-Southampton Creek through valley floor was lowered by approximately 50 feet following Pennypack Creek valley capture of its west oriented flow. Note how both the Pennsylvania Turnpike and adjacent rail line use higher ground north of the east oriented Pennypack Creek valley so as to maintain elevations necessary to cross the higher drainage divides in both the Dreshler through valley and the Mill-Southampton Creek through valley.

The east oriented Pennypack Creek valley was eroded by reversed flow on the west end of the beheaded west-southwest oriented channel that had been moving water via the Dreshler through valley to the Wissahickon Creek valley. Erosion of this deep east oriented valley required significant volumes of water and prior to Little Neshaminy Creek valley headward erosion that water flowed in a south direction via the Rosewood Park through valley seen in Figure 4. Today a south oriented tributary draining the Rosewood Park through valley south end joins southeast oriented Pennypack Creek headwaters with combined flow going in a south direction to the western end of the east oriented Pennypack Creek valley segment. The east oriented Pennypack Creek valley segment suggests headward erosion of the south oriented Pennypack-Southampton Creek valley first captured and beheaded the west oriented flow channel moving water across the present day south oriented Neshaminy Creek drainage basin to the Dreshler through valley and then to the Wissahickon Creek valley. Second, after that capture Neshaminy and Mill Creek valley headward erosion beheaded the west oriented flow channel across the Mill-Southampton Creek divide, but the south oriented channel that had eroded headward along the Rosewood Park through valley alignment was still capturing large volumes of southwest oriented floodwaters moving across the region north of the actively eroding Neshaminy Creek and Mill Creek valley heads. These captured floodwaters then moved south via the Rosewood Park through valley to the newly reversed channel and flowed in an east direction along the newly reversed flow channel to the much deeper south oriented Pennypack Creek valley and in the process eroded the east oriented Pennypack Creek valley segment. Third, headward erosion of the east oriented Little Neshaminy Creek valley next beheaded south oriented flow routes to the Rosewood Park through valley while west of the actively eroding Little Neshaminy Creek valley southwest oriented flow continued to move toward the Wissahickon Creek valley, which enabled the southeast oriented Pennypack Creek headwaters valley to erode into the region seen in Figure 3. Finally, Little Neshaminy Creek valley headward erosion beheaded all flood flow routes to the Pennypack drainage basin and major Pennypack Creek drainage 
basin landscape features have remained relatively unchanged since that time.

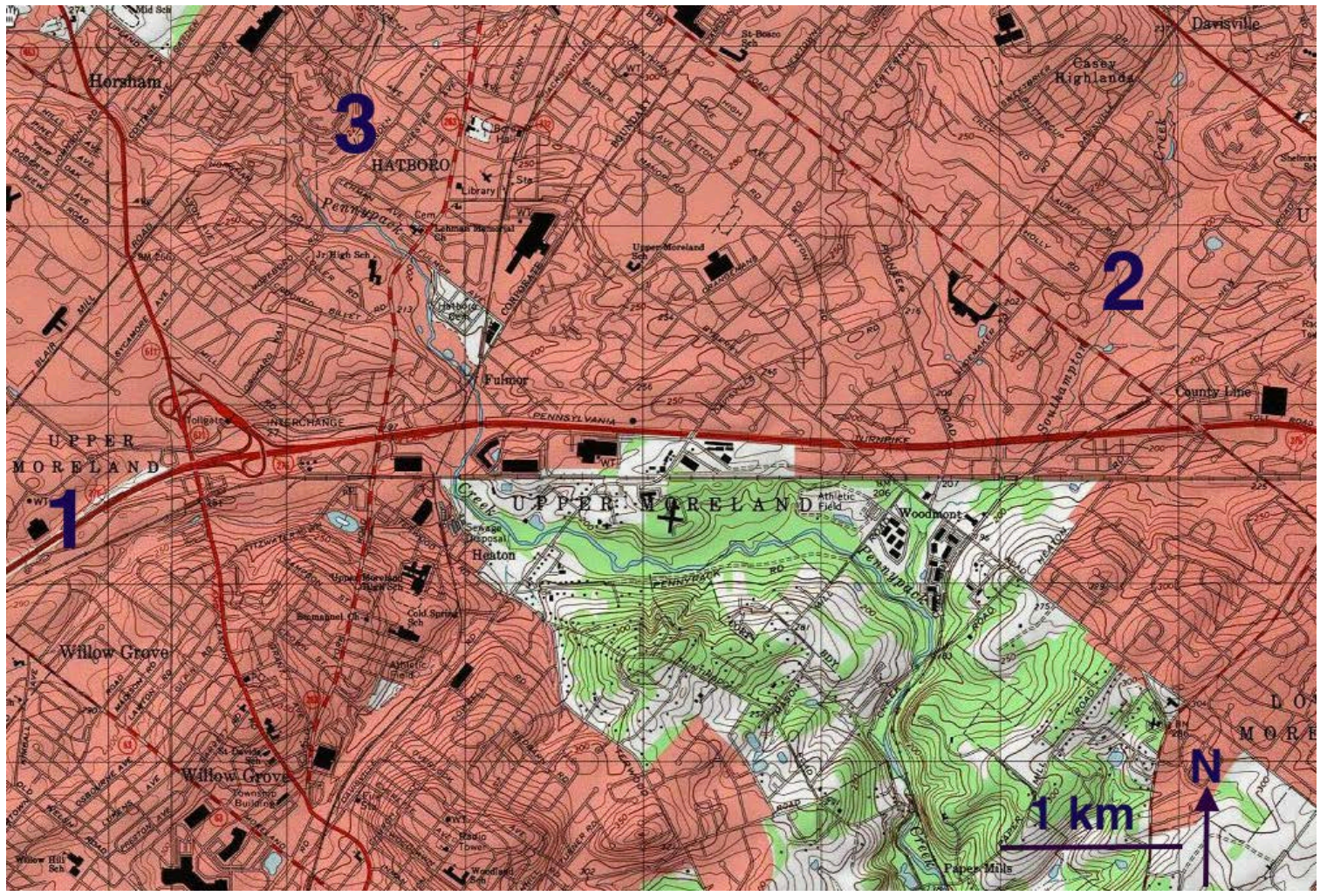

Figure 9. USGS 1:24,000-scale topographic map (10-foot contour interval) taken from Pennsylvania DCNR Interactive Map Resources website showing the east oriented Pennypack Creek valley link between the Dreshler through valley and the Mill-Southampton Creek through valley. Number 1 identifies the Dreshler through valley, 2 Southampton Creek, and 3 the south oriented Pennypack tributary draining from the Rosewood Park through valley. The rail line south of the Pennsylvania Turnpike continues in an east direction to the Mill-Southampton

Creek through valley

\section{Discussion}

Erosional landforms as depicted on detailed topographic maps show prior to Pennypack Creek drainage basin erosion massive southwest oriented floods crossed the entire drainage basin area. The most obvious evidence is the Huntingdon Valley and the more northern Dreshler through valley with their eastern extensions across the Pennypack-Neshaminy Creek drainage divide. These two through valleys extend from east of the south oriented Neshaminy Creek valley across the Pennypack Creek drainage basin to the south oriented Wissahickon Creek valley and provide evidence of at least two roughly parallel west-southwest oriented flow channels that were captured from west to east in an identifiable sequence by headward erosion of several deeper south oriented valleys. Evidence described here demonstrates headward erosion of the south oriented Wissahickon Creek valley captured flow in both channels first and that Tookany Creek headward erosion captured the Huntingdon Valley channel flow next, but did not erode far enough north to capture flow moving in the northern (Dreshler through valley) channel. Pennypack Creek valley headward erosion then captured flow in both channels with Poquessing Creek valley headward erosion capturing Huntingdon Valley channel flow, but not eroding north far enough to capture northern channel flow. Finally Neshaminy Creek valley headward erosion captured flow in both of the through valleys.

The progression of flow channel captures demonstrated here suggests south oriented stream valleys eroded headward from the southwest oriented Delaware River valley (and its southeast oriented Schuylkill River valley) in sequence from west to east and may mean south oriented valleys (including the south oriented Schuylkill-Wissahickon valley) eroded headward from an actively eroding and deep southwest-oriented Delaware River valley head. If so the southwest oriented Delaware River valley eroded headward along what must have been an extremely large southwest oriented flow channel carrying much more water than any of the described flow channels that crossed the Pennypack Creek drainage basin area. However, Pennypack Creek 
valley headward erosion across multiple flow channels suggests massive southwest oriented floods did cross the entire region and were not confined to the Delaware River valley area. The flood source and timing cannot be determined from southeast Pennsylvania topographic map evidence other than to say the water came from the northeast. The southwest flood flow direction is consistent with the Delaware River flow direction and also with flow directions determined from Bridgeton and Pensauken sedimentary deposits found adjacent to the Pennypack valley areas closest to the Delaware River (downstream from the area seen in Figure 8). Melting of a large continental ice sheet could have produced massive floods capable of overwhelming any existing drainage systems and then eroding completely new drainage basins in a manner similar to that described here for the Pennypack Creek drainage basin.

\section{References}

Bascom, F., Clark, W. B., Darton, N. H., Knapp, G. N., Kuemmel, H. B., Miller, B. L., \& Salisbury, R. D. (1909). Philadelphia folio, Norristown, Germantown, Chester, and Philadelphia, Pennsylvania-New Jersey-Delaware: Folios of the Geologic Atlas 162.

Bischke, R. E. (1980). The Abington-Cheltenham, PA. Earthquake Sequence of March-May, 1980: Pennsylvania Geology, 11(5), 10-13.

Braun, D. D., Pazzaglia, F. J., \& Potter, N. (2003). Margin of Laurentide Ice to the Atlantic Coastal Plain: Miocene-Pleistocene landscape evolution in the Central Appalachians: in Easterbrook, D. editor, Quaternary Geology of the United States: INQUA 2003 Field Guide Volume: Desert Research Institute, Reno, NV, p. 220.

Clausen, E. (2016). Using topographic map interpretation methods to determine Tookany (Tacony) Creek erosion history upstream from Philadelphia, Pennsylvania, USA: Journal of Geography and Geology, 8(4), 30-45. https://doi.org/10.5539/jgg.v8n4p30

Fenneman, N. M. (1938). Physiography of Eastern United States: McGraw-Hill Book Company, New York. 714 pp.

Ham, J., Toran, L., \& Cruz, J. (2006). Effect of upstream ponds on stream temperature: Environmental Geology, 50(1), 55-61. https://doi.org/10.1007/s00254-006-0186-4

Klein, T., \& Toran, L. (2016). Collocation of hydrological and biological attenuation of nitrate in an urban stream. Hydrological Processes, (30), 2948-2957. https://doi.org/10.1002/hyp.10821

Morisawa, M. (1989). The rivers and valleys of Pennsylvania, revisited: In Gardner, T. W. and Sevon, W. D. (Eds.) Appalachian Geomorphology. Geomorphology, (2), 1-22.

Owens, J. P. (1999). Cretaceous and Tertiary: in Schultz, C.H. Ed., The Geology of Pennsylvania: Pennsylvania Geological Survey, Harrisburg and Pittsburgh Geological Society, Pittsburgh. p. 218-223.

Pennsylvania Department of Conservation and Natural Resources, DCNR Interactive Map Resources, http://www.dcnr.state.pa.us/learn/interactivemapresources/index.htm

Philadelphia Water Department (PWD). (2009). Pennypack Creek Comprehensive Characterization Report: Philadelphia Water Department Office of Watersheds, 329 pp.

Potter, N, (1999). Part V: Physiography: in The Geology of Pennsylvania: Schultz, C. H., editor, Pennsylvania Geological Survey and Pittsburgh Geological Society. p. 342-344.

Sorrentino, J. A., Featherstone, J., \& Meenar, M. M. R. (2007). Applying the EPA's regional vulnerability assessment (ReVA) approach to the Pennypack Creek watershed. The Center for Sustainable Communities, Temple University, Ambler Campus, 183 pp. Retrieved from https://www.researchgate.net/publication/ 266232678_Applying_the_EPA's_Regional_Vulnerability_Assessment_ReVA_Approach_to_the_Pennypac k_Creek_Watershed

Stanford, S. D. (2010). Pliocene and Quaternary Geology of the Trenton area: in Lacombe, Pierre, editor, Geology of the Greater Trenton area and its impact on the Capital City: Twenty Seventh Annual Meeting of the Geological Association of New Jersey Field Guide and Proceedings: p. 120-131.

Steele, L. (2010). History of Pennypack Trust: 1970-2010: From Watershed Association to Land Trust: Pennypack Ecological Restoration Trust, Huntingdon Valley, PA. http://pennypacktrust.org/wp-content/uploads/2014/09/pennypack_40yr_history.pdf

Strahler, A. N. (1945). Hypotheses of stream development in the folded Appalachians: Geological Society of America Bulletin, 56(1), 45-88. https://doi.org/10.1130/0016-7606(1945)56[45:HOSDIT]2.0.CO;2 
Strahler, A. N. (1952). Dynamic basis of geomorphology. Geological Society of America Bulletin, (63), 923-938. https://doi.org/10.1130/0016-7606(1952)63[923:DBOG]2.0.CO;2

Thornbury, W. D. (1965) Regional Geomorphology of the United States: John Wiley and Sons, New York. 610 pp.

United States Geological Survey Historical Map Collection (1899). Germantown, PA 1:62,500 scale topographic map. Accessed from https://ngmdb.usgs.gov/maps/TopoView

United States Geological Survey Historical Map Collection (1997). Frankford, PA 1:24,00 scale topographic map. Accessed from https://ngmdb.usgs.gov/maps/TopoView

United States Geological Survey Historical Map Collection (1997). Germantown, PA 1:24,000 scale topographic map. Accessed from https://ngmdb.usgs.gov/maps/TopoView

United States Geological Survey Historical Map Collection (1999). Ambler, PA 1:24,00 scale topographic map. Accessed from https://ngmdb.usgs.gov/maps/TopoView

United States Geological Survey Historical Map Collection (1999). Hatboro, PA 1:24,00 scale topographic map. Accessed from https://ngmdb.usgs.gov/maps/TopoView

\section{Copyrights}

Copyright for this article is retained by the author(s), with first publication rights granted to the journal.

This is an open-access article distributed under the terms and conditions of the Creative Commons Attribution license (http://creativecommons.org/licenses/by/4.0/). 